\title{
CXXII. THE COLLOIDAL PROPERTIES OF SERUM.
}

\author{
By CECIL INNES BOTHWELL VOGE \\ (Carnegie Research Scholar).
}

From the Animal Breeding Research Department, University of Edinburgh.

(Received July 15th, 1929.)

I. Changes in the colloidal properties of Serum in syphilitics.

WRIGHT and KERMACK [1923, 2] investigated the mechanism of precipitation of colloidal gum benzoin by cerebrospinal fluid, and concluded that the abnormal precipitation associated with a fluid from a case of general paralysis of the insane was due to the presence of some abnormal constituent.

It is the object of the present communication to show that syphilitic serum differs from normal serum in a similar manner, and that the abnormal constituent is capable of being separated together with the water-insoluble serum fraction, the euglobulin.

\section{EXPERIMENTAL.}

Serum was examined under conditions which allowed the hydrogen ion concentration to vary simultaneously with the serum concentration. This was effected in the following manner. A block of test-tubes was arranged in rows 'and columns, each column corresponding to one of the serum concentrations and each row to one of the dilutions of acid or alkali. $0.5 \mathrm{cc}$. of serum was added to each tube in the corresponding column and a similar volume of acid, alkali or water to each tube in the corresponding row. $1 \mathrm{cc}$. of Sumatra gum benzoin sol, prepared as described by Kermack and Voge [1925], was now added to each tube. The tubes were shaken, allowed to stand overnight and then read, the conventional method adopted in the previous communications being employed $\left(4=\right.$ complete precipitation, $0=$ no precipitation, etc.). The $p_{\mathrm{H}}$ of the supernatant fluid in those tubes in which complete precipitation was recorded was determined colorimetrically; the areas of protection were shown by the addition of $1 \mathrm{cc} .4 \%$ sodium chloride solution to those tubes in which no precipitation occurred; the charges upon the particles, in those tubes in which no precipitation was recorded, were determined by ultramicroscopic examination where the drift of the particles was observed under the influence of an electric field; and finally the method of recording these findings was by means of a graph in which the $p_{\mathrm{H}}$ is the ordinate and the concentration of serum the abscissa. The above is a very short résumé of the methods employed in this research as they are already set out at length by Wright and Kermack 
[1923, 1, 2], Kermack and Voge [1925] and Voge [1928]. The method employed for separating the water-insoluble serum-protein fraction with which is associated the syphilitic substance is described elsewhere Voge [1929, 1].

The experiments described in this research are representative and have been taken from the large numbers examined. In the preliminary work human blood-serum was alone employed, but latterly owing to the difficulty of obtaining sufficient material the use of ascitic fluid was decided upon. It was found that from the point of view of this investigation no significant difference could be demonstrated, the difference in protein concentration being the most marked. This material was therefore employed in all the experiments here enumerated, and owing to the large quantities available it enabled numerous experiments to be performed upon the same fluid.

Table I shows the precipitating effect of normal serum upon gum benzoin sol, the actual precipitation in each tube being shown by this method of recording. Fig. 1 shows the graphic method.

The main points to be noted in this figure are that a zone of precipitation divides those particles which bear a positive charge from those upon which a negative charge exists, and that an area of complete protection exists at concentration of serum $S / 4$ at all points where the $p_{\mathrm{H}}$ value is greater than $7 \cdot 2$.

Table I. Showing precipitating effect of normal serum upon colloidal gum benzoin under the influence of varying $\mathrm{p}_{H}$ (cf. Fig. 1).

Concentration of serum

\begin{tabular}{|c|c|c|c|c|c|c|c|c|c|c|c|c|c|c|c|}
\hline $\mathrm{HCl}$ & $\frac{5}{\infty}$ & $\frac{\infty}{\infty}$ & $\stackrel{0}{\infty}$ & 约 & $\frac{d}{\infty}$ & $\stackrel{\stackrel{\infty}{*}}{\underset{\infty}{*}}$ & 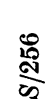 & $\frac{\tilde{N}}{\infty}$ & 1 & 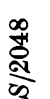 & 1 & $\frac{\mathscr{\sigma}}{\infty}$ & 1 & 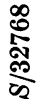 & 1 \\
\hline$N / 25$ & $0^{\prime \prime}$ & $0^{\prime \prime}$ & $0^{\prime \prime}$ & $0^{\prime \prime}$ & $0^{\prime \prime}$ & $0^{\prime \prime}$ & $0^{\prime \prime}$ & $0^{\prime \prime}$ & $0^{\prime \prime}$ & $0^{\prime \prime}$ & $0^{\prime}$ & 0 & 2 & 4 & 4 \\
\hline 50 & $0^{\prime \prime}$ & $0^{\prime \prime}$ & $0^{\prime \prime}$ & $0^{\prime \prime}$ & $0^{\prime \prime}$ & $0^{\prime \prime}$ & $0^{\prime \prime}$ & $0^{\prime \prime}$ & $0^{\prime \prime}$ & $0^{\prime \prime}$ & 0 & 0 & 0 & 0 & 3 \\
\hline 100 & $\mathbf{3}^{\prime \prime}$ & $0^{\prime \prime}$ & $0^{\prime \prime}$ & $0^{\prime \prime}$ & $0^{\prime \prime}$ & $0^{\prime \prime}$ & $0^{\prime \prime}$ & $0^{\prime \prime}$ & $0^{\prime}$ & 0 & 0 & 0 & 0 & 4 & 4 \\
\hline 200 & 4 & 3 & $0^{\prime \prime}$ & $0^{\prime \prime}$ & $0^{\prime \prime}$ & $0^{\prime \prime}$ & $0^{\prime \prime}$ & $0^{\prime}$ & $0^{\prime}$ & 0 & 0 & 0 & 0 & 4 & $\$$ \\
\hline 400 & $0^{\prime \prime}$ & 4 & 4 & $0^{\prime \prime}$ & $0^{\prime \prime}$ & $0^{\prime \prime}$ & $0^{\prime \prime}$ & $0^{\prime \prime}$ & $0^{\prime}$ & 0 & 0 & 0 & 0 & 4 & 4 \\
\hline 800 & $0^{\prime \prime}$ & $0^{\prime \prime}$ & 4 & 4 & $0^{\prime \prime}$ & $0^{\prime \prime}$ & $0^{\prime \prime}$ & $0^{\prime \prime}$ & $0^{\prime}$ & 0 & 0 & 0 & 0 & 4 & 4 \\
\hline 1600 & $0^{\prime \prime}$ & $0^{\prime \prime}$ & 4 & 4 & 4 & $0^{\prime \prime}$ & $0^{\prime \prime}$ & $0^{\prime \prime}$ & $0^{\prime}$ & 0 & 0 & 0 & 4 & 4 & 4 \\
\hline 3200 & $0^{\prime \prime}$ & $0^{\prime \prime}$ & $0^{\prime \prime}$ & 3 & 4 & $0^{\prime \prime}$ & $0^{\prime}$ & 0 & 0 & 0 & 0 & 0 & 4 & 0 & 0 \\
\hline 6400 & $0^{\prime \prime}$ & $0^{\prime \prime}$ & $0^{\prime}$ & 4 & 4 & 3 & $0^{\prime}$ & 0 & 0 & 0 & 0 & 0 & 4 & 0 & 0 \\
\hline $\mathrm{H}_{2} \mathrm{O}$ & $0^{\prime \prime}$ & $0^{\prime \prime}$ & $0^{\prime \prime}$ & $0^{\prime}$ & 4 & 4 & 4 & 4 & 0 & 0 & 2 & 4 & 4 & 0 & 0 \\
\hline 6400 & $0^{\prime \prime}$ & $0^{\prime \prime}$ & $0^{\prime \prime}$ & $0^{\prime}$ & 4 & 4 & 4 & 4 & 4 & 4 & 4 & 0 & 0 & 0 & 0 \\
\hline 3200 & $0^{\prime \prime}$ & $0^{\prime \prime}$ & $0^{\prime \prime}$ & $0^{\prime}$ & $0^{\prime}$ & 4 & A & 0 & 0 & 0 & 0 & 0 & 0 & 0 & ) \\
\hline 1600 & $0^{\prime \prime}$ & $0^{\prime \prime}$ & $0^{\prime \prime}$ & $0^{\prime \prime}$ & $0^{\prime \prime}$ & $0^{\prime \prime}$ & $0^{\prime \prime}$ & $0^{\prime}$ & 0 & 0 & 0 & 0 & 0 & 0 & 0 \\
\hline 800 & $0^{\prime \prime}$ & $0^{\prime \prime}$ & $0^{\prime \prime}$ & $0^{\prime \prime}$ & $0^{\prime \prime}$ & $0^{\prime \prime}$ & $0^{\prime \prime}$ & $0^{\prime \prime}$ & $0^{\prime}$ & 0 & 0 & 0 & 0 & 0 & 0 \\
\hline$N / 400$ & $0^{\prime \prime}$ & $0^{\prime \prime}$ & $0^{\prime \prime}$ & $0^{\prime \prime}$ & $0^{\prime \prime}$ & $0^{\prime \prime}$ & $0^{\prime \prime}$ & $0^{\prime \prime}$ & $0^{\prime \prime}$ & $0^{\prime}$ & 0 & 0 & 0 & 0 & 0 \\
\hline
\end{tabular}

Fig. 2 shows the precipitating effect of syphilitic ascitic fluid upon gum benzoin sol. When this is compared with Fig. 1 it is observed that at a concentration of fluid $S / 4$, precipitation of the sol occurs up to $p_{\mathrm{H}} 9$ instead of $p_{\mathrm{H}}$ 7.2. In the normal serum the area above this latter $p_{\mathrm{H}}$ is one wherein complete protection exists. In the syphilitic serum it would appear that some substance is present which is capable of so altering the stability of normal 
serum-proteins that they precipitate in the presence of a negatively charged sol such as gum benzoin. This would indicate that the abnormal constituent was capable of conferring a positive charge upon the normal serum-proteins and is in keeping with the hypothesis advanced by Wright and Kermack $[1923,2]$, who suggested that if such a substance were protein in nature it

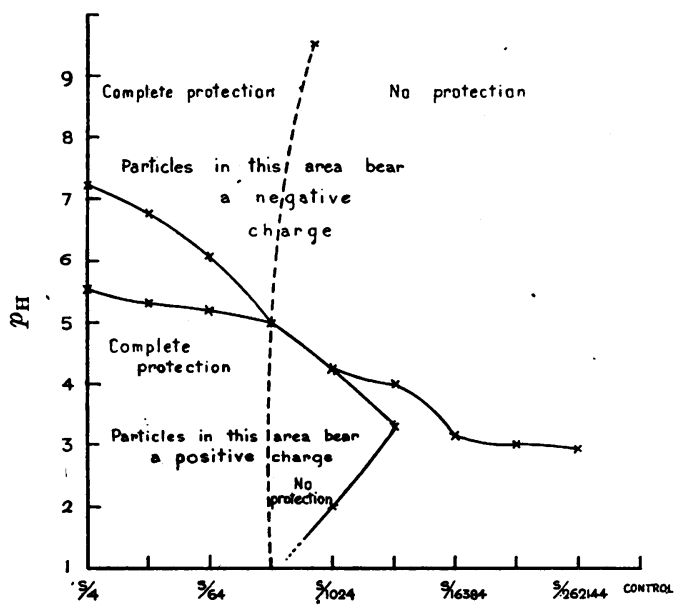

Fig. 1. The precipitating effect of normal human ascitic fluid upon colloidal gum benzoin.

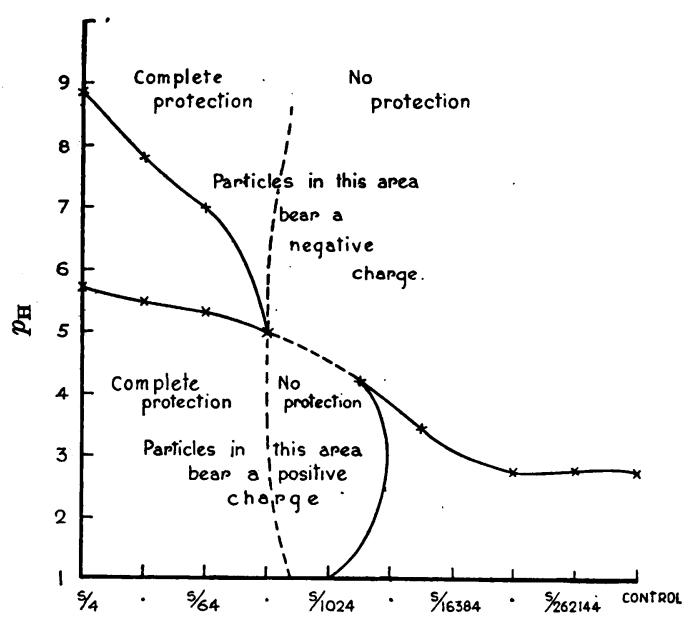

Fig. 2. The precipitating effect of syphilitic human ascitic fluid upon colloidal gum benzoin.

must possess a high isoelectric point. It is a well-known fact that proteins bear a positive charge at all points upon the acid side of their isoelectric point and so only a protein possessing an isoelectric point of $p_{\mathrm{H}} 9$ or greater would be capable of conferring a positive charge upon the normal serum-proteins existing at a $p_{\mathrm{H}}$ lower than this value. That such a mechanism is at work and 
that such a protein is responsible for this change in the stability of the normal serum-proteins is shown to be feasible and these points are fully discussed in a later section.

It is well-known that, in the Wassermann reaction, the degree of heating to which a serum is subjected before being submitted to the test influences the fixation of complement in a syphilitic serum. It has been shown that if serum be submitted to a preliminary heating at $55^{\circ}$ the area of precipitation in the first zone, serum concentrations $S / 4-S / 256$, is slightly altered in normal serum, and markedly altered in serum from a syphilitic source. In normal serum after heating at this temperature for $30 \mathrm{~min}$. precipitation is found to occur within the limits of $p_{\mathrm{H}} 5-6$, thus showing a distinct increase in the area of complete protection occurring above this $p_{\mathrm{H}}$ value. In syphilitic serum no change is observed until the serum has been heated at this temperature for a period longer than $30 \mathrm{~min}$. It is found, however, that after heating for $90 \mathrm{~min}$. the area of precipitation is in no way different from that shown by normal serum after 30 minutes' heating, and thus the area of complete protection, which in syphilitic serum is found only at a $p_{\mathrm{H}}$ value greater than 9 , has been increased in area until it reaches $p_{\mathrm{H}} 6$. Similar experiments carried out upon serum fractions, as prepared in the succeeding section, have shown that the change which occurs in the precipitating power is associated with the serumeuglobulin fraction.

Considerable diversity of opinion has existed from time to time as to the fraction with which the syphilitic substance is associated in serum. Serum fractions have been prepared by various methods and the only one in which a clean-cut separation has been attained is that described by Voge [1929, 1], separation of the water-insoluble serum-proteins being effected by dialysis. It was found that if dialysis was continued for the correct length of time all the original amount of syphilitic substance was found associated with this fraction. The amount present was demonstrated before and after dialysis by means of the Sigma test. Table II demonstrates these facts.

Table II.

\begin{tabular}{|c|c|c|c|c|}
\hline & \multirow[b]{2}{*}{$\begin{array}{l}\text { Sigma value } \\
\text { of whole serum }\end{array}$} & \multirow{2}{*}{$\begin{array}{l}\text { Fraction of serum } \\
\text { insoluble in } \\
\text { distilled water. } \\
\text { Euglobulin } \\
\text { units }\end{array}$} & \multicolumn{2}{|c|}{$\begin{array}{l}\text { Fraction of serum soluble in } \\
\text { distilled water }\end{array}$} \\
\hline & & & Pseudoglobulin & Albumin \\
\hline 1 & 11 & 11 & 0 & $\mathbf{0}$ \\
\hline 2 & 10 & 8 & 0 & 0 \\
\hline 3 & $34+$ & $34+$ & 0 & 0 \\
\hline & $34+$ & $34+$ & 0 & 0 \\
\hline 5 & 20 & 17 & 0 & 0 \\
\hline 6 & 85 & 85 & 0 & 0 \\
\hline 7 & 0 & 0 & 0 & 0 \\
\hline
\end{tabular}

In carrying out the Sigma test the fractions for examination were submitted to a previous heating for 90 minutes at $55^{\circ}$. The Wassermann test was carried out on the above fractions and a fixation of six doses of complement was recorded for sera 1-6 in the water-insoluble fraction, no fixation 
being shown to occur in the other fractions. For this latter test the sera were subjected to a preliminary heating for 30 minutes at $55^{\circ}$.

The fraction insoluble in distilled water was taken up in Ringer's solution, the volume used being sufficient to give the same concentration of euglobulin as present in the original serum. The serum fractions soluble in distilled water were separated by half saturated and saturated ammonium sulphate respectively, dialysed to remove this salt and the solid constituents of Ringer's solution added before being submitted to the test.

Fractions prepared in a similar manner were examined under conditions where the protein concentration was allowed to vary as well as the $p_{\mathrm{H}}$ value to determine the precipitating effect of these upon gum benzoin sol. It was observed that increased precipitation was obtained with euglobulin from syphilitic serum, the zone of precipitation in protein concentration $S / 4$ extending from $p_{\mathrm{H}} 7$ to $8 \cdot 2$, as compared with normal euglobulin $p_{\mathrm{H}} 6 \cdot 8$ to $7 \cdot 2$.

\section{The efFect of addition of a protamine, Clupeine SUlphate,} TO NORMAL SERUM.

Wright and Kermack [1923, 2] have suggested that the alterations discussed in section I may be due, not to the ordinary serum-proteins, but to the presence of some other material, which, if protein in nature, must be possessed of a high isoelectric point. In 1926 Dr Kermack suggested to me that the addition of a protamine to normal serum might cause it to simulate syphilitic serum in its precipitating power. The methods of experimentation used were those described in section I. The results are presented in Fig. 3, which shows the effect of the addition of $0.5 \%$ of a protamine, clupeine sulphate, to $9.5 \mathrm{cc}$. of normal serum. This serum gave the same precipitating effect as that described in the previous section, Fig. 1, but the addition of this basic protein caused it to simulate the syphilitic serum shown in Fig. 2.

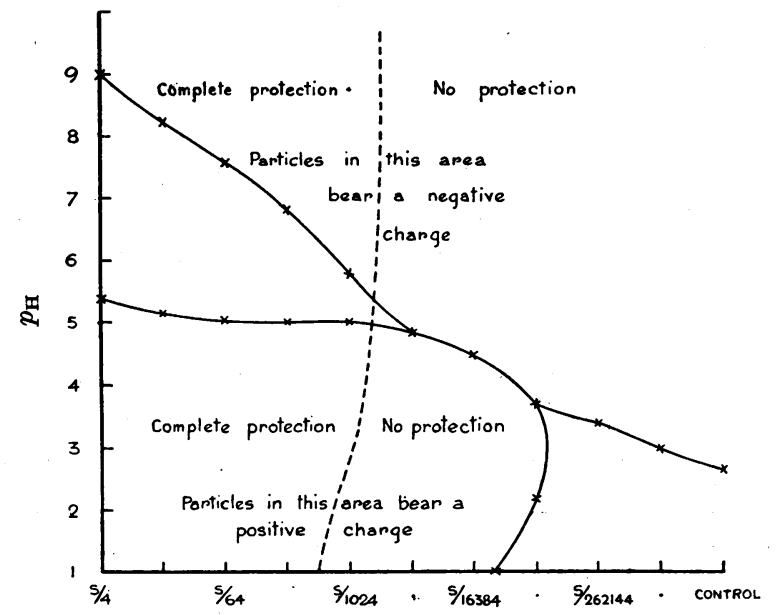

Fig. 3. The precipitating effect of normal human ascitic fluid to which has been added clupeine sulphate. (Compare Figs. 1 and 2.) 
It has also been shown that this change is associated with the serumeuglobulin fraction, for when serum is dialysed and the water-insoluble fraction removed, dissolved in Ringer's solution and tested, this fraction alone gives in protein concentration $S / 4$, precipitation up to $p_{\mathbf{H}} 8.8$. The effect of heating such a mixture, normal serum and clupeine sulphate, is to decrease the zone of precipitation in proportion to the time of heating until, after 90 minutes, the zone of precipitation is similar to that given by normal serum.

Wolf and Rideal [1926] came to the conclusion that clupeine sulphate added to normal serum-globulin does not cause it to simulate globulin from syphilitic serum. These authors commenced their protein concentrations at $1 / 100$ and complete or almost complete precipitation is recorded by them in the first two tubes. Similar experiments carried out by us commenced at $1 / 4$ protein concentration and complete precipitation of the gum benzoin sol occurred up to $1 / 200$ protein concentration. We would therefore suggest that our results are almost identical, the interpretation alone being different. These authors regard the zone of precipitation which occurs at a concentration greater than $1 / 500$ as being the zone of increased precipitation in syphilis, whereas we regard this zone to be indicated by the precipitation which occurs in concentrations less than $1 / 200$, the essential differences between normal and syphilitic serum being found in concentrations $S / 4, S / 8, S / 16$.

Further work has been carried out to ascertain the effect of the addition of clupeine sulphate to normal serum upon the Wassermann and Sigma reactions. It has been found that in the latter a strong positive reaction normally associated with syphilitic serum, i.e. 68 units, is obtained. The effects in the Wassermann reaction appear to be more complex. A fixation of six doses is found to occur but beyond this value anti-complementary readings are obtained, i.e. fixation of complement occurs in the absence of antigen. The effect of heating such serum mixtures before testing was studied. In the first series of experiments the temperature was kept constant but the period of heating was varied. It was shown that heating at $55^{\circ}$ for longer than 30 minutes decreased the power to fix complement. In the second series the period of heating, 30 minutes, was kept constant but the temperature was varied, readings being made at $55^{\circ}, 58^{\circ}$ and $60^{\circ}$. At a higher temperature than $55^{\circ}$ the capacity of such serum mixtures to fix complement was gradually destroyed. Details of these experiments will be submitted in a later communication.

\section{The colloidal Chemistry of agglutination WITH SPECIAL REFERENCE \\ TO THE POSSIBLE ISOLATION OF A SERUM FRACTION RICH IN ANTIBODIES.}

The object of this investigation was to study the precipitating effects of normal and immune serum upon a specific sol. A bacillary emulsion such as is employed in the following experiments is called the "antigen," inasmuch as, when it is injected, the antiserum produced contains antibodies which possess the power to precipitate the specific antigen in vitro. 
The method discussed in the previous sections whereby the serum concentration was allowed to vary as well as the hydrogen ion concentration was adopted in all the experiments. In order to conform to normal agglutination technique the volumes were in all cases decreased, $0 \cdot 2 \mathrm{cc}$. of serum being employed, a similar volume of acid or alkali, and $0.5 \mathrm{cc}$. of the antigen. The dilutions of all materials were carried out with distilled water so that the results might be compared with those previously obtained with a non-specific system, and in some cases gum benzoin sol was employed as an antigen to ascertain its effect.

The interpretation of the results was made in the same manner as before (see Fig. 4).

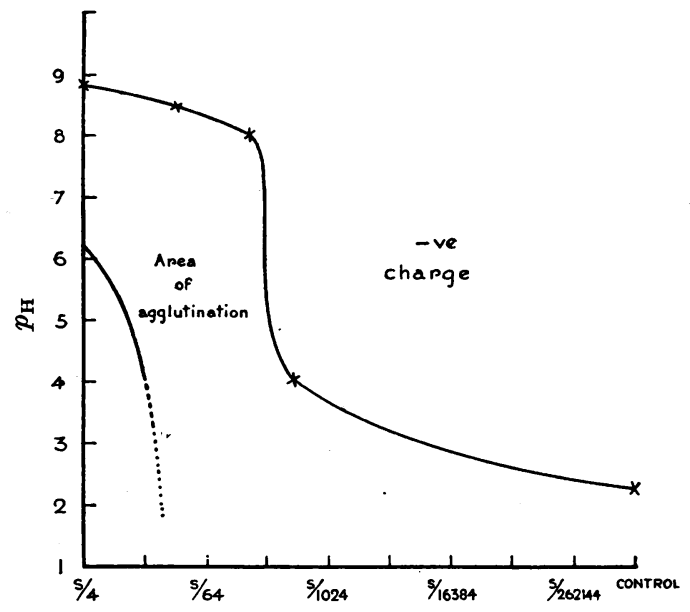

Fig. 4. The agglutinating effect of $B$. abortus antiserum upon a suspension of $B$. abortus (Bang).

NotE. The agglutinating effect of normal cows' serum upon a suspension of this organism is similar to the precipitating effects shown in Fig. 1.

The sera of cattle were employed throughout this research and the antigen was obtained by washing off an 18 hour growth of $B$. abortus on nutrient agar with $0.85 \%$ sodium chloride and adjusting the opacity of the emulsion to that given by No. 7 of Brown's opacity tubes. The sera of fifteen cattle have been examined by the methods outlined above, about half possessing a serum agglutination titre against $B$. abortus of about $1: 200$, the remaining half being entirely negative. Two representative cases gave the following agglutination titres with $B$. abortus antigen.

1. The serum from cow xiv gave a positive agglutination titre of $1: 300$. This serum has been employed for demonstrating the precipitating or agglutinating effect of antiserum.

2. The serum of cow $\mathrm{xV}$ gave a negative agglutination test (agglutinating titre only $1: 4)$. This serum has been employed for demonstrating the precipitating or agglutinating effect of normal serum. 


\section{Discussion.}

The precipitating effect of normal and $B$. abortus antiserum upon gum benzoin sol is in nowise greatly dissimilar to that shown by human serum in section I. The agglutinating effect of normal cows' serum upon B. abortus antigen is also very similar. In the above three systems no precipitation or agglutination is found to occur with a serum concentration of $S / 4$ at a $p_{\mathrm{H}}$ value greater than 8.2. It is noted that the $p_{\mathbf{H}}$ is a little higher than that which was shown to be the upper limit in human serum but the difference does not appear to be significant considering that serum from a different species is employed.

Fig. 4 shows the agglutinating effect of $B$. abortus antiserum upon $B$. abortus antigen. It will be observed that a very large increase in agglutinating power has occurred. The upper limit of agglutination at serum concentration $S / 4$ occurs at $p_{\mathrm{H}} 8 \cdot 8$ and at $S / 128$ at $p_{\mathrm{H}} 8$.

It is apparent that this abnormal agglutination shown by $B$. abortus antiserum is only given when the specific antigen is employed.

The above experiments have been carried out with unheated serum but when the serum had previously been heated at $55^{\circ}$ for half an hour the abnormal zone of agglutination shown by $B$. abortus antiserum was considerably reduced, approaching that of normal serum.

There appear to be several points in common between the phenomena discussed in the previous sections wherein a non-specific system such as the precipitation of normal and syphilitic serum is discussed. Firstly, the abnormal zone of agglutination is associated with the serum-euglobulin fraction. Secondly, the effect of submitting the serum to a preliminary heating at $55^{\circ}$ for half an hour is to decrease the zone of agglutination and, in the case of antiserum, if inactivated for a longer period the agglutination shown is similar to that given by normal serum. Thirdly, the effect of the presence of this agglutinin is to raise the limit of agglutination in serum concentration $S / 4$ from $p_{\mathrm{H}} \mathbf{7 \cdot 5}$ to $8 \cdot 8$. In normal serum the proteins in this concentration and at these $p_{\mathrm{H}}$ values confer a protection upon the particles of the antigen and so, not only does agglutination not occur, but even the subsequent addition of $4 \%$ sodium chloride fails to agglutinate the organisms, which under these conditions bear a negative charge. The effect of agglutinin appears to be very similar to that demonstrated previously by the addition of a basic protein to normal serum whereby the normal negative charge upon the proteins is so altered that upon the addition of a negatively charged sol precipitation, or in this case agglutination, ensues.

It has been shown that gum benzoin sol is not more readily precipitated by antiserum than by normal serum and in a similar manner it was demonstrated that the addition of clupeine sulphate to normal cows' serum did not, in the concentrations employed, cause it to simulate antiserum. It would appear that, although there are many points in common between the non- 
specific and specific reactions which appear to indicate that the production of antibodies or agglutinins is accompanied by an alteration of the charge upon the serum-proteins, there is a radical difference which is responsible for the specificity of interaction between antiserum and organism.

In view of the similarities that appeared to exist, it was thought to be of interest to attempt to isolate the water-insoluble serum fraction. This was done by submitting a high titre serum to dialysis, according to the method described by Voge $[1929,1]$, whereby the water-insoluble euglobulin and associated agglutinin can be separated. This finding is in keeping with the results of Kroeger and Hektoen [1927]. Rosenholz [1928] has demonstrated that the active fraction of anti-anthrax serum is adsorbed with the euglobulin. Such fractions separated by dialysis from the whole serum have been prepared, and experiments have been carried out to ascertain whether they are able to confer an immunity against a subsequent infection with the specific organism. The results so far obtained have been most promising although the numbers of animals employed have been too few to furnish conclusive evidence [Voge, $1929,2]$.

\section{Summary.}

1. Normal and syphilitic sera behave differently in their power to precipitate gum benzoin sol. In syphilitic serum a zone of precipitation exists which is not present in normal serum. An abnormal substance is present in syphilitic serum which possesses the power of conferring a positive charge upon the serum-proteins and so rendering them unstable in the presence of a negatively charged sol such as gum benzoin sol.

2. Normal serum undergoes little change when heated at $55^{\circ}$ for periods up to 90 minutes; syphilitic serum at the end of this period is indistinguishable in its precipitating effects from normal serum, although little alteration appears to have occurred after heating it at this temperature for 30 minutes.

3. The abnormal substance present in syphilitic serum is associated with the serum-euglobulin fraction, with which it can be separated from the other serum fractions.

4. The effect of the addition of very small quantities of a protamine to normal serum is to cause this latter to simulate syphilitic serum in its precipitating and complement-fixing powers. The effect of heating a serum so treated is to cause it to regain its normal precipitating and complementfixing powers and so in this respect it is similar to syphilitic serum.

5. Normal serum and antiserum possess a similar precipitating power upon gum benzoin sol. An almost similar degree of agglutinating power is shown by normal serum upon an antigen of $B$. abortus.

6. The marked agglutinating power of antiserum upon a suspension of B. abortus is greatly diminished by subjecting the antiserum to preliminary heating. 
7. The substance responsible for the agglutinating power is associated with the serum-euglobulin fraction.

Sections I and II form part of a thesis submitted for the degree of Ph.D., Edinburgh University [Voge, 1928]. This research was commenced in the laboratory of the Royal College of Physicians with the financial assistance of the Department of Scientific and Industrial Research, and continued in the laboratories of the Animal Breeding Research Department, Edinburgh during the tenure of a Carnegie Scholarship.

For hospitality and financial assistance from these bodies grateful thanks are rendered.

My thanks are also due to Dr W. O. Kermack for advice and criticism.

\section{REFERENCES.}

Kermack and Voge (1925). Proc. Roy. Soc. Edin. 45, 1, x, 90.

Kroeger and Hektoen (1927). Proc. Soc. Exp. Biol. Med. 24, 352.

Rosenholz (1928). Z. exp. Biol. Med. 10, 109.

Voge (1928). Thesis, Edinburgh University.

- $(1929,1)$. Biochem. J. 23, 185.

- $(1929,2)$. In the press.

Wolf and Rideal (1926). J. Hyg. 25, 366.

Wright and Kermack (1923, 1). Biochem. J. 17, 635.

- $(1923,2)$. Biochem. J. 17, 658. 